\title{
The origin of tiger salamander (Ambystoma tigrinum) populations in California, Oregon, and Nevada: introductions or relicts?
}

\author{
Jarrett R. Johnson • Robert C. Thomson • \\ Steven J. Micheletti $\cdot$ H. Bradley Shaffer
}

Received: 19 November 2009/Accepted: 19 September 2010/Published online: 21 October 2010

(C) The Author(s) 2010. This article is published with open access at Springerlink.com

\begin{abstract}
Whether intentionally or accidentally introduced, exotic species have the capacity to dramatically disrupt native communities. In central California, tiger salamanders (Ambystoma tigrinum) have been introduced as a by-product of the sport fishing bait industry. Some of these introductions are relatively well known and have resulted in the formation of hybrids with the imperiled native California tiger salamander (A. californiense). Other populations of A. tigrinum, particularly in the northern and eastern parts of the state, remain poorly characterized and are present in regions where relictual amphibian populations of other species have persisted, suggesting that these might be relictual, native A tigrinum. We used genetic sequence data to determine the provenance of all known extralimital A. tigrinum populations in California and adjacent Oregon and Nevada through comparison with reference samples from the native range of A. tigrinum. Our results suggest that $A$. tigrinum have been introduced
\end{abstract}

J. R. Johnson ( $\square)$. R. C. Thomson · S. J. Micheletti ·

H. B. Shaffer

Department of Evolution and Ecology, University of California,

Davis, CA 95616, USA

e-mail: jarrett.johnson@wku.edu

J. R. Johnson - R. C. Thomson - H. B. Shaffer

Center for Population Biology, University of California,

Davis, CA 95616, USA

Present Address:

J. R. Johnson

Department of Biology, Western Kentucky University,

Bowling Green, KY 42101, USA

Present Address:

S. J. Micheletti

Department of Biology, San Francisco State University,

San Francisco, CA 94132, USA in Northern California, Southern California and the Sierra Nevada, originating from multiple sources across the Great Plains of the US. Furthermore, two populations near the California-Oregon border are most closely related to A. tigrinum populations from Washington and Oregon and may represent native tiger salamander lineages.

Keywords Hybridization - Introduced species · Mitochondrial DNA · Non-indigenous species

\section{Introduction}

The anthropogenic spread of species beyond their natural ranges has long been recognized as a negative consequence of the globalization of human activities (Elton 1958). Nonindigenous species threaten the biodiversity of native communities and perturb ecosystem function through predation, competition, and habitat alteration (Lodge 1993; Kolar and Lodge 2001). In addition, when introductions bring closely related species into secondary contact, hybridization and "genetic extinction" may occur (Rhymer and Simberloff 1996).

Non-indigenous species have been identified as a major threat to global amphibian diversity (e.g., Blaustein and Wake 1990; Beebee and Griffiths 2005; Kraus 2009) and particularly California amphibian diversity (Bury and Luckenbach 1976; Fisher and Shaffer 1996). Well-known examples of non-indigenous species that negatively affect California's native amphibians through competition and predation include bullfrogs (Rana catesbeiana; Moyle 1973; Kupferberg 1997; Kiesecker and Blaustein 1998; Pearl et al. 2004), crayfishes (Gamradt and Kats 1996) and fishes (Hayes and Jennings 1986; Bradford 1989; Gamradt and Kats 1996; Lawler et al. 1999; Knapp and Matthews 
2000). Additionally, tiger salamanders (Ambystoma tigrinum) have been widely introduced into California and throughout the western United States (Collins et al. 1988), leading to hybridization with native populations (Riley et al. 2003; Storfer et al. 2004) and the widespread potential for the spread of disease (Picco and Collins 2008). Hybridization is an often-overlooked consequence of biological invasions because it occurs more rarely and is more difficult to detect than the effects of competition and predation. But the effects of genetic invasions can be great (Allendorf et al. 2001), and there are now several examples of the negative effects of hybridization with non-indigenous amphibian taxa (Arntzen and Thorpe 1999; Storfer et al. 2004; Holsbeek et al. 2008; Ryan et al. 2009; Fitzpatrick et al. 2010).

The tiger salamander is a wide-ranging North American species that occurs from the East Coast of the United States across the Great Plains and into the Colorado, Wyoming, and Utah Rocky Mountains. Tiger salamanders are generally absent from the Great Basin deserts of Utah, Nevada, Oregon, and California, but natural populations occur in the Palouse Prairie region of central and eastern Washington (Nussbaum et al. 1983). The Washington portion of the range is disjunct from more eastern US populations in the shortgrass prairie of Montana, Idaho and Wyoming, with a distributional break along the Snake River Valley of Idaho. Ambystoma tigrinum has traditionally been viewed as consisting of six subspecies that exhibit variation in life history characteristics, behavior, and morphology (Petranka 1998). Molecular divergence estimates are high between the eastern and western forms of A. tigrinum, and low among the western subspecies (Shaffer and McKnight 1996), leading some authors to recognize two species (A. tigrinum in the east, A. mavortium in the west) and abandon subspecies designations for the western taxa A. diaboli, A. mavortium, A. melanostictum, and A. nebulosum (e.g., Stebbins 2003). Given the considerable uncertainty surrounding the systematics of the group, we continue to use the traditional classification, and refer to all of these taxa as A. tigrinum.

Currently, three types of tiger salamanders are recognized in California. (1) The California tiger salamander (A. californiense) occupies the Central Valley and inner coast ranges of central and southern California (Shaffer and Trenham 2005) and is distinct from A. tigrinum with respect to ecology and life-history characteristics (Petranka 1998). The California tiger salamander is a California endemic species and is listed as "Threatened" (in the central part of its range) or "Endangered" (in Sonoma and Santa Barbara Counties) under the US Endangered Species Act, and is considered a threatened species under the California Endangered Species Act. (2) A. californiense $\times$ A. tigrinum hybrids result from intentional introductions of
A. tigrinum into the Salinas Valley of California (Riley et al. 2003). Hybridization in the Salinas Valley has resulted in the introgression of non-native genes into native populations through a large fraction of A. californiense's native range (Fitzpatrick et al. 2009). (3) Numerous other populations of A. tigrinum have been reported in California and nearby Oregon and Nevada. These populations occur outside the range of both A. californiense and A. tigrinum as isolated populations in Northern California, Southern California and Great Basin habitats east of the Sierra Nevada (Fig. 1). It is on this third set of populations that we focus our attention in this paper.

Based on both morphology (Mullen and Stebbins 1978) and limited mtDNA genotyping (Shaffer and McKnight 1996) these populations are clearly neither A. californiense

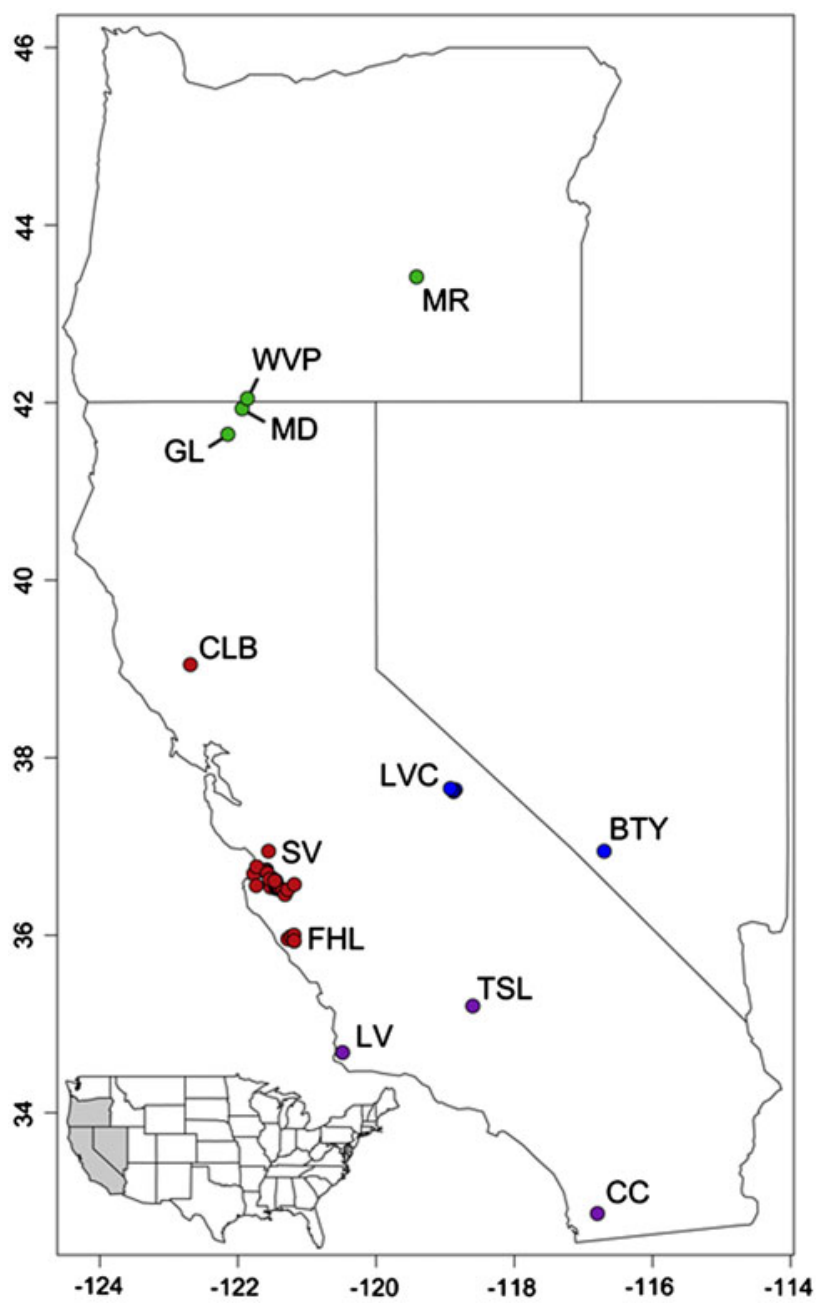

Fig. 1 Map of extralimital populations sampled. MR Moon Reservoir; GL Grass Lake; $M D$ MacDoel Ditch; WVP Worden Vernal Pool; $C L B$ Clear Lake Basin; $L V C$ Long Valley Caldera; BTY Beatty; $S V$ Salinas Valley; FHL Fort Hunter-Liggett; TSL Tom Sawyer Lake; LV Lompoc Valley; CC Chocolate Canyon. Colors represent a priori relatedness hypotheses based on geography and known introductions. See text for discussion of specific hypotheses 
nor A. californiense $\times$ A. tigrinum hybrids leaving two reasonable alternatives for their distributional status. One possibility is that some or all of these populations are relictual A. tigrinum lineages surviving from the wetter Pleistocene. Alternatively, these populations may represent introductions from the "bait-bucket" release of nonindigenous A. tigrinum larvae. Both hypotheses are plausible. The Northern Leopard Frog (Rana pipiens), Oregon Spotted Frog (Rana pretiosa), and Long-Toed Salamander (Ambystoma macrodactylum) are pond-breeding amphibians that also have relictual populations in some of these same areas, making it possible that native A. tigrinum lineages may have survived in isolated mesic habitat patches in eastern and northern California (Stebbins 2003). Given the extreme sensitivity of these and other isolated relictual amphibian populations (Jennings and Hayes 1994), it is important both from biogeographic and management perspectives to determine whether these extralimital tiger salamander populations are native, sensitive, and potentially endangered, or introduced, exotic populations that should not be protected, and possibly eliminated.

Tiger salamander larvae are frequently used as fish bait and historically have been harvested from wild populations to supply the bait industry (Slater 1934; Mullen and Stebbins 1978; Collins 1981; Collins et al. 1988; Riley et al. 2003), likely altering the natural distributions of tiger salamanders (Collins 1981; Storfer et al. 2004). This confusion was discussed more than three decades ago, when Mullen and Stebbins (1978) proposed that the isolated, extralimital tiger salamander population discovered in far Northern California at Grass Lake (Siskiyou County, CA) might represent a relictual population of tiger salamanders native to California rather than an introduced bait-bucket release. If the conjecture of Mullen and Stebbins (1978) is correct, and native, relictual $A$. tigrinum lineages exist in California, it is important to identify and protect these rare, vulnerable populations.

Our objective in this study was to use DNA sequence data to help determine whether extralimital populations of A. tigrinum are representatives of a rare relictual native salamander, or are the result of recent, human-mediated introductions. We collected data for all known A. tigrinum populations in California and adjacent Oregon and Nevada, and compared genetic sequence data from each population with reference samples from within the native range of A. tigrinum. We sequenced a large (1379 base pair) fragment of mitochondrial DNA from population-level samples of all extralimital populations and a thorough sampling of native lineages from throughout the western range of the species to determine the native/exotic status of each extralimital population of A. tigrinum.

Unambiguously determining the status of such populations is challenging, particularly when levels of genetic divergence are low. In this case, we reasoned that if we found mtDNA haplotypes within an extralimital A. tigrinum population that are distinct from all sampled reference populations from the native range of A. tigrinum and are phylogenetically similar to a geographically nearby reference population, this would be most consistent with the interpretation that the extralimital population shared a common ancestor with nearby relatives, but has long existed in isolation. In this situation, we would conclude that the extralimital population is likely a native relict. For example, if extralimital populations in northern California are distinct from, but most similar to, reference populations in eastern Washington, then they are probably natural, disjunct populations that were possibly separated from those in Washington during post-Pleistocene climatic drying. Alternatively, if an extralimital population of A. tigrinum shares identical haplotypes with a geographically distant reference population (say, from the Great Plains) to the exclusion of nearby reference populations, we would infer that the extralimital population has been recently introduced from that distant location.

The patterns of molecular variation observed may also provide clues on the origin of extralimital populations. For example, if a set of relictual populations were derived from a previously continuous population that was isolated during the drying of the Great Basin, those populations should collectively form a monophyletic group. But if they represent independent human-mediated introductions, there is no reason why all or most extralimital populations should form a monophyletic group, particularly if the introductions were from multiple sites.

Finally, data from known introductions can inform our analysis. Based on extensive genetic analyses and interviews with local bait dealers, it is now firmly established that the widely distributed non-native A. tigrinum genotypes in the Salinas Valley of central California were intentionally introduced in the 1950s (Riley et al. 2003; Fitzpatrick and Shaffer 2007). If the mitochondrial variation observed in an extralimital site consists primarily of the same haplotypes as those found in introduced tiger salamanders from the Salinas Valley, we can reasonably conclude that they are also recently introduced, and do not represent a cryptic native Californian A. tigrinum lineage.

Our motivation is to use these results to inform management decisions regarding the protection of relictual native California A. tigrinum, or alternatively support the eradication of non-indigenous $A$. tigrinum that threaten the persistence of native species, including the California tiger salamander, (A. californiense; Fitzpatrick et al. 2009), the Santa Cruz long-toed salamander (A. macrodactylum croceum; Ryan et al. 2009), and the Owens Tui Chub (Siphateles bicolor snyderi; Chen et al. 2007). Given the predatory habits and ability to rapidly reproduce as large, 
paedomorphic and/or terrestrial adults, determining the status of extralimital A. tigrinum and initiating either protection or eradication are important management goals both for the salamanders and the vernal pool ecosystems that they inhabit.

\section{Methods}

\section{Sampling}

We identified four regions where A. tigrinum have been documented in California and adjacent Oregon and Nevada (Fig. 1; see Table 1 in Appendix). (1) The Klamath Basin region of Northern California and Oregon includes three collection localities along US Highway 97: Grass Lake, CA, MacDoel, CA, and Worden, OR. Additionally, we included a fourth population in central Oregon from an artificial stock pond near Moon Reservoir (Fig. 1). We group these four populations together based on the a priori hypothesis that they are relictual populations that have been isolated from extant range of A. tigrinum in Washington. The Grass Lake population has previously been described tentatively as a native A. tigrinum lineage in California (Mullen and Stebbins 1978; Stebbins 2003) or as a non-indigenous population of A. tigrinum melanostictum (Bury and Luckenbach 1976). (2) The Long Valley Caldera region includes four collection localities near Mammoth Lakes, CA along Highway 395 and an additional location near Beatty, NV (Fig. 1). These populations have been grouped based on the hypothesis that they have been isolated from the western part of the range of A. tigrinum in Utah by the drying of the Great Basin. Little is known regarding the Mammoth Lakes tiger salamander populations except that they potentially have direct negative effects on local endangered native fish populations, and are therefore candidates for eradication if they are in fact nonindigenous (S. Parmenter, pers. comm.). (3) The Salinas Valley region includes 38 collection localities ranging from Gilroy, CA to Soledad, CA along Highway 101, an additional six sites at Fort Hunter Liggett, CA, and a single collection locality in the Clear Lake Basin region near Clearlake Oaks, CA at the-now abandoned-Five Star Fish Farm (Fig. 1). These populations are the result of hybridization between native, resident $A$. californiense and known introductions by Don Green and other fish bait dealers in the 1950s (Riley et al. 2003; Fitzpatrick and Shaffer 2007). We include these populations in our analyses, as they could potentially be the introduction source for the other extralimital populations in California. Based on our extensive previous work on these populations, we included only previously genotyped individuals that contained non-native mitochondrial haplotypes based on single nucleotide polymorphism (SNP) genotypes obtained for the mtDNA Control Region (CR) marker (Fitzpatrick and Shaffer 2007). We included animals from the Five Star Fish Farm in this region based on verbal confirmation from one of the bait dealers that these animals were derived from his initial introductions into the Salinas Valley. (4) In Southern California, we group three geographically distinct populations based on a lack of a clear biogeographic hypothesis. We have two collection sites in the Lompoc Valley near Lompoc, CA, a single individual collected in Chocolate Canyon near Alpine, CA (Ervin and Burkhardt 2006), and an additional population at Tom Sawyer Lake near Tehachapi, CA. (Fig. 1). The Lompoc populations are believed to be non-indigenous and have previously been subjected to eradication measures (L. Hunt, pers. comm.). In total, we included 58 localities and 344 individuals in our set of extralimital populations (see Table 1 in Appendix). To the best of our knowledge, this is an exhaustive set of extralimital A. tigrinum populations in, or adjacent to California.

Native populations that we used for comparative purposes (hereafter referred to as reference samples) included numerous collection localities from within the known native range of A. tigrinum in the United States (Fig. 2; see Table 1 in Appendix). We included 1-4 individuals $(N=128)$ from each of 82 collection localities spanning the native range of $A$. tigrinum except the geographically restricted and endangered Sonoran Tiger Salamander, A. $t$. stebbinsi.

\section{DNA extraction and amplification}

We extracted DNA from tail or liver tissue that was either preserved in $95 \%$ ethanol or frozen at $-80^{\circ} \mathrm{C}$ using a standard salt extraction protocol (Sambrook and Russell 2001). Given the very low levels of nuclear divergence among members of the tiger salamander complex, including some of our target taxa (Weisrock et al. 2006), we focused exclusively on mitochondrial DNA in this study. We designed oligonucleotide primers for the mitochondrial control region (CR), and NADH dehydrogenase subunit 2 (ND2) using Primer3 (Rozen and Skaletsky 2000) and sequences downloaded from GenBank. ND2 was chosen because of its high variability in Ambystoma (Samuels et al. 2005) and CR was used to build on previously available comparative data (Shaffer and McKnight 1996; Storfer et al. 2004). Mitochondrial DNA (mtDNA) was amplified using the polymerase chain reaction (PCR) on Eppendorf Mastercycler Ep gradient thermal cyclers. Our PCR protocol was as follows: initial denaturation at $94^{\circ} \mathrm{C}$ for $7 \mathrm{~min}, 20$ cycles of $30 \mathrm{~s} 94^{\circ} \mathrm{C}$ denaturation, $30 \mathrm{~s}$ $60^{\circ} \mathrm{C}$ annealing, and $1 \mathrm{~min} 72^{\circ} \mathrm{C}$ elongation, and a single $72^{\circ} \mathrm{C}$ final elongation for $10 \mathrm{~min}$. Successful amplification 


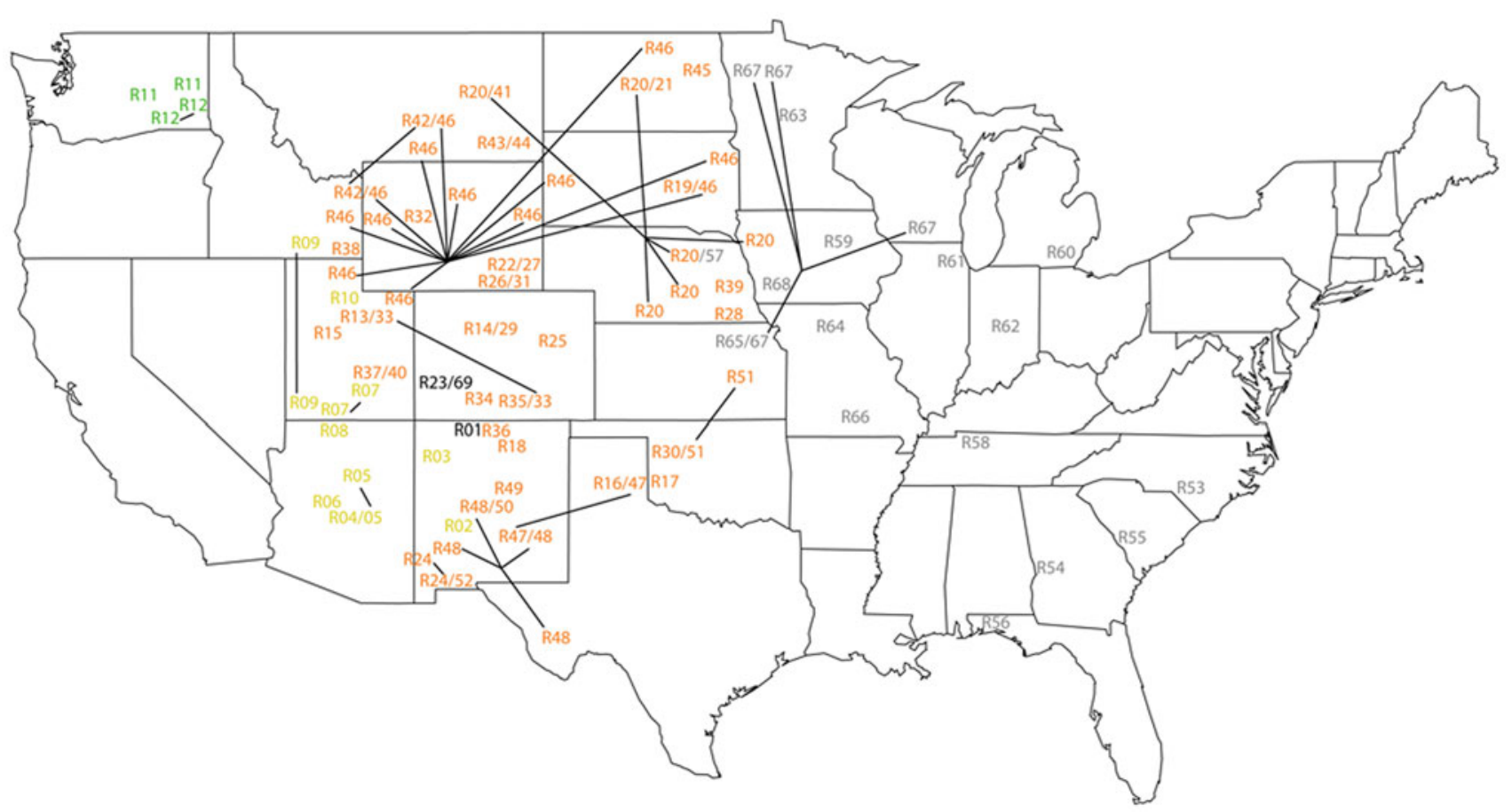

Fig. 2 Map of reference populations sampled for A. tigrinum. Haplotype numbers are placed at collecting localities. Lines connecting haplotypes are for reference only and are intended to improve the ability to locate localities sharing a given haplotype. Green denotes the Pacific Northwest clade, brown denotes the Northern Great Plains clade, and orange represents the Southern Great Plains clade. Gray represents Eastern A. tigrinum (not associated with any extralimital populations) of PCR product was visualized on $1 \%$ agarose gels, and the size of the PCR fragment was assessed with Low Mass DNA Ladder.

\section{Sequencing and phylogenetic analysis}

PCR product was purified and sequenced using Agencourt's Single Pass Sequencing service. This service includes template purification of PCR amplicons, DNA sequencing reactions with BigDye Terminator v3.1, and sequence delineation on an ABI PRISM 3730xl. Sequences for each gene were verified by GenBank BLAST searches and alignment with GenBank sequences. We aligned all sequences using MUSCLE (Edgar 2004) and concatenated data from each gene. Alignments were checked and adjusted by eye, verifying that the ND2 data translated properly.

Our strategy was to first characterize the haplotype pool present at each of the extralimital A. tigrinum populations, as well as the geographic distribution of haplotypes in the known native range. We identified the unique haplotypes from all of the extralimital populations and from the reference set separately, and analyzed this complete set of haplotypes. Thus, the same haplotype could occur twice on the resulting phylogenetic tree if it was present in both the reference and extralimital populations. Using this combined set of haplotypes we inferred a single phylogenetic gene tree by partitioning the alignment by gene and carrying out a maximum-likelihood bootstrapping search in RAxML (Stamatakis et al. 2008). We then attempted to phylogenetically assign the extralimital haplotypes to known native haplotypes (or haplotype groups if it fell within a native cluster but was not identical to any native haplotype) based on the resulting topology.

We also generated a phylogenetic network of our concatenated data using SplitsTree version 4.10 (Huson and Bryant 2006) with uncorrected "p" genetic distances and the NeighborNet algorithm (Bryant and Moulton 2004). We also performed a bootstrap analysis with 1000 replicates implemented in SplitsTree. Phylogenetic networks may provide additional insight into the complexities of the relationships present in data such as ours that are obscured when using a single phylogenetic tree (Huson 1998). We used both the network and phylogenetic information in combination with the geographic proximity of native and extralimital sites, to infer the most likely origin of each set of extralimital populations.

\section{Results}

We amplified 725 bp of CR and 655 bp of ND2 for a total of $1379 \mathrm{bp}$ of mtDNA sequence for each individual. We 
recovered 69 unique reference sample haplotypes of A. tigrinum subspecies (see Table 1 in Appendix). Haplotype codes and catalogue numbers used in this study are annotated in the sequence information uploaded to GenBank (HM544136-HM545077). Across the individuals sampled from extralimital populations of A. tigrinum (including $A$. californiense $\times A$. tigrinum hybrids), we identified 35 unique extralimital haplotypes (see Table 1 in Appendix). As expected, there was relatively little variation available for phylogenetic analysis, and ML bootstrap values were often low (Fig. 3). Our goal, however, was to compare extralimital haplotypes with reference native sites, rather than to infer a robust phylogeny of A. tigrinum, and the data were generally variable enough for this purpose. The major splits of the phylogenetic network (Fig. 4) mirrored the well-supported clades present in the phylogenetic tree (Fig. 3).

From the Klamath Basin, we sequenced 17 individuals from Grass Lake, 19 individuals from MacDoel Ditch, and seven individuals from Worden Vernal Pool. The Klamath Basin populations display an interesting pattern in which the southernmost site (Grass Lake) is entirely composed of
Fig. 3 Maximum-likelihood phylogram of haplotypes. Numbers at nodes are bootstrap proportions $>70$. Color and haplotype name refers to position in Fig. 2. See Table 1 in Appendix for more locality information. Highlighted clades contain extralimital haplotypes and correspond with colored labels on Fig. 2

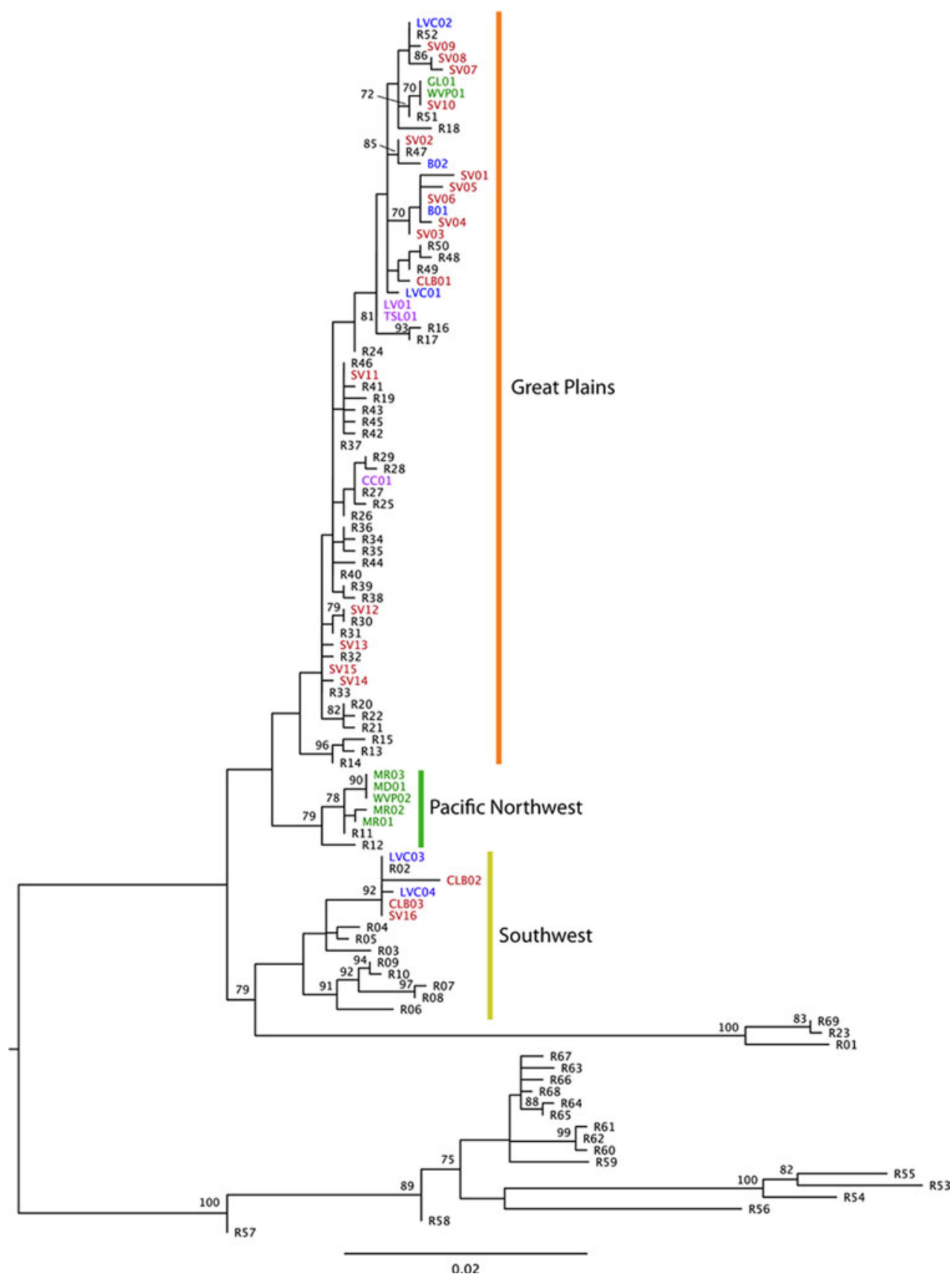




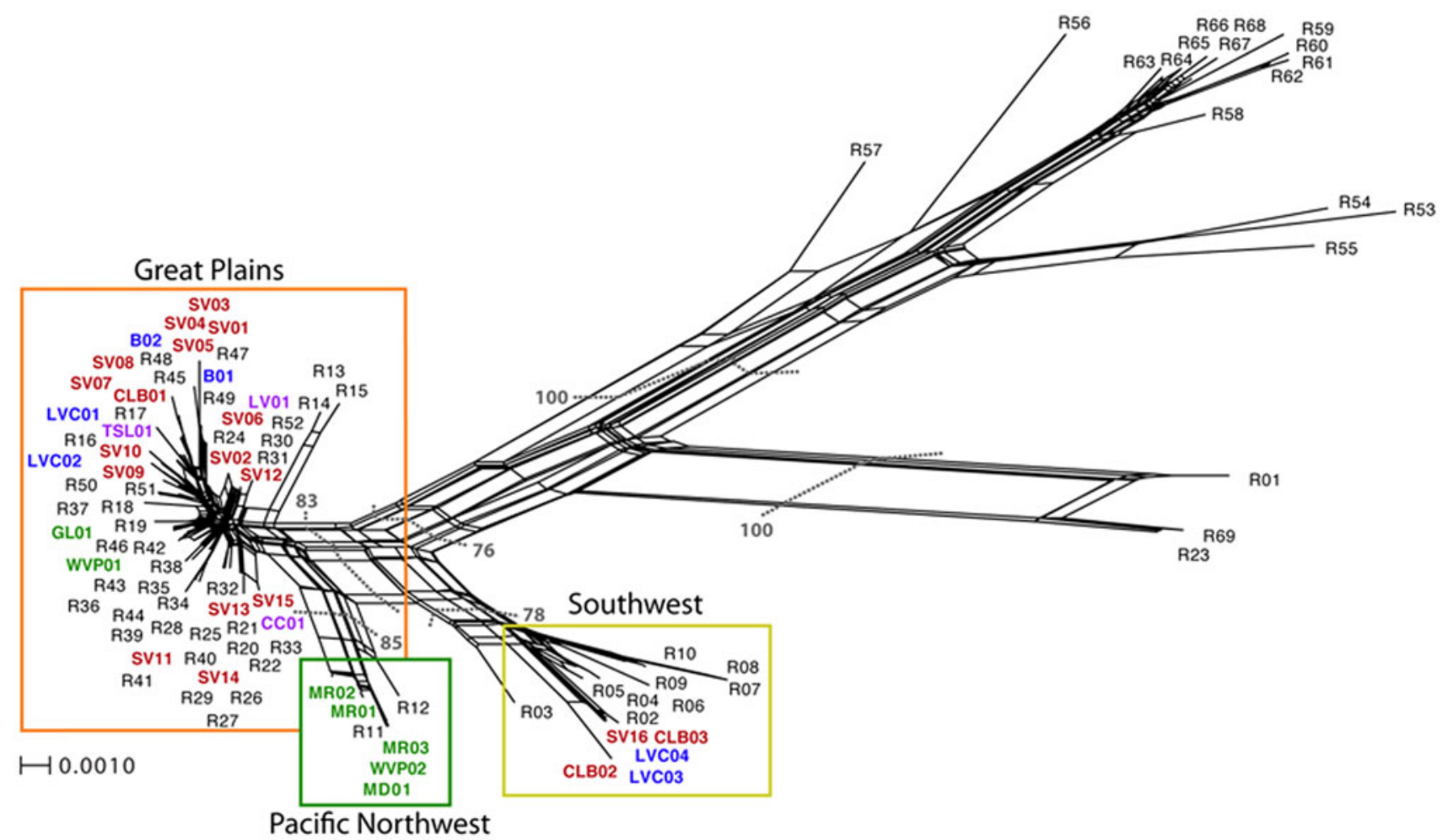

Fig. 4 Phylogenetic network of haplotypes. Color and haplotype name refers to position in Fig. 2. See Table 1 in Appendix for more locality information. Highlighted clades contain extralimital haplotypes and correspond with colored labels on Fig. 2. Bootstrap support values for the major clades are labeled in gray with dotted lines denoting the splits. We omitted support values for all smaller clades and larger clades with values $<70$

individuals from Laurel Pond, a large, artificial pond. The Long Valley Caldera region revealed four haplotypes, two that were common (LVC01 and LVC02), one that was rare but present at three of four sites ( $\mathrm{LVCO} 3)$ and the last (LV04) represented by a single individual. The LVC03 haplotype is identical to other non-indigenous haplotypes (CLB03 and SV16) and reference haplotype R02 from New Mexico (Fig. 3). LVC02 falls within a clade with several Salinas Valley haplotypes (SV07-09), and is identical to reference haplotype R52 from New Mexico. LVC01 is not strongly associated with any particular reference haplotype but falls within the large Great Plains clade that includes the Salinas Valley and other extralimital haplotypes, as well as a collection of reference haplotypes from New Mexico, Oklahoma, and Texas (Fig. 3). The four individuals sampled from the Beatty, $\mathrm{NV}$ population revealed two haplotypes (B01 and B02). B01 was identical to SV06 from the Salinas Valley, and both B01 and B02 are nested within the Great Plains clade containing many known non-indigenous Salinas Valley haplotypes.

We sequenced up to five individuals from each of the 44 Salinas Valley region localities. The Salinas Valley region contained almost half of the haplotype diversity present in all of the extralimital populations (16/36). Several Salinas 
Valley haplotypes were identical to reference haplotypes. For example, the "Bluestone Quarry" haplotype (SV02) and a reference haplotype from New Mexico and Texas (R47), and a "Fort Hunter-Liggett" haplotype (SV12) and a reference haplotype from Oklahoma (R30) form two such pairs (Fig. 3). Many Salinas Valley haplotypes (SV11-14) are associated with reference haplotypes from the Great Plains but lack strong bootstrap support (Fig. 3). The most common Salinas Valley haplotype (SV16) was associated with a Southwest clade containing reference haplotypes from Arizona, Idaho, New Mexico, and Utah (Fig. 2). The somewhat isolated Fort Hunter-Liggett populations are $\sim 60 \mathrm{~km}$ south of the upper Salinas Valley populations and contain two haplotypes (SV07 and SV08) that were distinct from the rest of the Salinas Valley, but remain nested within the Great Plains clade (Fig. 3). The Fort HunterLiggett populations also shared the most common Salinas Valley haplotype (SV16) with the upper Salinas Valley populations (Fig. 3). We sequenced 52 individuals from the Five-Star Fish Farm in the Clear Lake Basin. This population revealed only three haplotypes despite extensive sampling over multiple years, and one of these haplotypes (CLB02) was only present in a single individual. Of the remaining two common Clear Lake Basin haplotypes, CLB01 clustered with haplotypes in the Great Plains clade from New Mexico and Texas (R48-50), while CLB03 was identical to haplotypes R02 from New Mexico, SV16 from the Salinas Valley, and LVC03 from the Long Valley Caldera in the Southwest clade (Fig. 3).

The Lompoc Valley region of southern California revealed a single haplotype (LV01) that was shared only with the two individuals sequenced from the Tom Sawyer Lake (TSL01) population. This haplotype was unique and not found in any of our reference samples, but fell within the large Great Plains reference haplotype clade containing most of the non-indigenous Salinas Valley samples (Fig. 3). The single Chocolate Canyon individual from extreme southern California contained a haplotype (CC01) that is identical to reference haplotype R27 from Wyoming (Fig. 3).

\section{Discussion}

Our sequence data shed new light on the question of whether extralimital A. tigrinum populations in California and adjacent Oregon and Nevada harbor relict native lineages or are the result of recent, human-mediated introductions. Given the broad distribution, and the potential for separate histories of each set of extralimital populations, we discuss the evidence for or against human-mediated introduction for each region separately.

The Northern California Klamath Basin populations are likely the result of two separate and recent introductions into California. Our data suggest that the Grass Lake population has likely resulted from a single human-mediated introduction from stock similar to that released into the Salinas Valley. This conclusion is in contrast to an earlier study that used morphological measurements to evaluate the taxonomic relationship of Grass Lake salamanders with other subspecies of A. tigrinum (Mullen and Stebbins 1978). Our reasoning for this conflicting conclusion is simple; the lone Grass Lake haplotype is identical to a haplotype detected in the Salinas Valley where we know that human-mediated introductions occurred, and similar to a reference haplotype found in Oklahoma and Kansas. We conclude that only a single introduction event may be responsible for this population based on the lack of haplotype diversity despite extensive sampling over multiple years. Alternatively, the low haplotype diversity can be explained by repeated population bottlenecks due to the isolated location of Grass Lake and the presumed low population sizes that would be necessary to allow the population to have gone undetected prior to 1969 (Mullen and Stebbins 1978). The sequence identity of the Grass Lake haplotype with a known non-indigenous haplotype from the Salinas Valley (SV10) and an Oklahoma/Kansas reference haplotype (R51), to the exclusion of more geographically proximate native A. tigrinum haplotypes from eastern Washington (R11-12) is compelling evidence for our conclusion that the Grass Lake population is nonindigenous. Additionally, the discovery of tiger salamanders at Grass Lake in 1969 (Mullen and Stebbins 1978) roughly 10-20 years after the large-scale introductions into the Salinas Valley and subsequent transfer to other areas in California (e.g., Clear Lake Basin), further supports our conclusion that the Grass Lake population is nonindigenous.

The other two Klamath Basin populations in MacDoel, CA and Worden, OR also exhibit low haplotype diversity. Twenty five of 26 individuals shared a single haplotype, which was also shared with the Moon Reservoir population in Oregon. Ecologically, the Moon Reservoir population seems like a strong candidate for being non-indigenous (Stebbins 2003); it occurs in a highly modified habitat (to our knowledge, a single, artificial stock pond), and there is a history of fish stocking (and sport fishing) in the vicinity (Bowers et al. 1999). However, genetically the Moon Reservoir population is closely associated with haplotypes from the native range of A. tigrinum from eastern Washington and with the geographically proximal populations from MacDoel Ditch and Worden Vernal Pool. From the genetic data alone, we conclude that the Moon Reservoir, MacDoel Ditch, and Worden Vernal Pool populations represent either the expansion of salamanders from the native range of A. tigrinum in Washington (either naturally or via human intervention), or remnant native A. tigrinum 
populations from a once large metapopulation that became isolated following Pleistocene drying. We cannot distinguish between these two alternative hypotheses with our data. Furthermore, we detected a shared haplotype between Grass Lake (GL01) and Worden Vernal Pool (WVP01) suggesting that either natural or human-mediated movements could be resulting in the admixture of these two distinct salamander lineages. If the MacDoel Ditch and Worden Vernal Pool populations are native, hybridization with lineages from Grass Lake presents an immediate risk of biodiversity loss via hybridization. Based on our data, it remains possible that the A. tigrinum populations at MacDoel Ditch in far-northern California and Worden Vernal Pool in extreme-southern Oregon are native. Until additional data are obtained, we suggest that these populations should be protected from immigration of non-indigenous tiger salamander lineages and considered potential candidates for management as threatened populations.

The Clear Lake Basin haplotypes are genetically in agreement with the statements of bait dealers that animals introduced into the Five Star Fish Farm were of the same stock introduced into the Salinas Valley in the 1950s. Furthermore, the Salinas Valley haplotype diversity likely reflects the diversity encountered by bait dealers in the native range of $A$. tigrinum from which the stock was collected for the initial large-scale introductions. While we cannot make precise conclusions from our phylogeny, it is interesting that we have recovered a strongly supported Southwest clade containing Salinas Valley haplotypes that are distinct from the Great Plains clade. The variation observed among introduced Salinas Valley haplotypes makes sense because the bait-dealers stopped at multiple locations during their collections. Interviews with one of the individuals involved in the introductions (Don Green) indicated that animals were collected from a variety of locations including Arizona, Colorado, and Texas (Riley et al. 2003), and our genetic results are consistent with this verbal account. In total, we have found that the salamander stock introduced into the Salinas Valley overlaps with haplotypes from throughout the western native range of A. tigrinum. However, based on these genetic results, it appears that the primary source of the introductions was closely related to populations in central New Mexico (R02 and R47-50; Fig. 2).

The populations at Fort Hunter-Liggett may represent the combination of introductions from the native range of A. tigrinum and transfer of individuals from the Salinas Valley. A previous investigation of the Fort Hunter-Liggett sites revealed that these populations were composed primarily of A. tigrinum genes, with low levels of native A. californiense also present (Fitzpatrick and Shaffer 2007). Our data suggest that some of the non-indigenous haplotypes encountered at Fort Hunter-Liggett were potentially transferred from the upper Salinas Valley populations, as several haplotypes are shared between the two regions. However, we cannot say whether the native haplotypes identified by Fitzpatrick and Shaffer (2007) were similarly transferred from the Salinas Valley or present before the introductions.

The four Long Valley Caldera populations demonstrated high within-site haplotype diversity relative to other heavily sampled population (e.g., Clear Lake Basin, Klamath Valley). Each of the four Long Valley Caldera breeding site shared haplotypes with other sites in the region, which is not surprising given their close geographic association (our four sampling sites are within $6.5 \mathrm{~km}$ of each other). The haplotypes of the Long Valley Caldera region were placed in the phylogeny in both the Great Plains and Southwest clades, containing much of the Salinas Valley non-indigenous haplotype diversity. Thus, the phylogenetic placement of the Long Valley Caldera haplotypes mimics the distribution of Salinas Valley haplotypes, suggesting either a common pattern of introductions or sequential introductions from one region to another. Specifically, the two most common Long Valley Caldera haplotypes are highly associated with the "Christiansen Agricultural Pond" (see Table 1 in Appendix), which is almost entirely non-native at nuclear SNP markers (JR Johnson and HB Shaffer, unpublished data), and the Five Star Fish Farm introduction site, as well as reference populations from New Mexico which we believe were near the actual collection sites. The Long Valley Caldera region shows no evidence of relict $A$. tigrinum lineages despite heavy sampling effort over multiple years and all known breeding sites. These A. tigrinum populations frequently produce paedomorphic (i.e., large, sexually mature, gilled adults) individuals that have the potential to negatively impact endangered fishes through direct predation (Steve Parmenter pers. comm.). Because the available evidence is consistent with the interpretation that the salamander populations in the Long Valley Caldera region are the result of introductions of exotic A. tigrinum, we feel that management action in accordance with preventing negative interactions with the Owens Valley fishes is appropriate. The Beatty, NV haplotypes are strongly associated with Salinas Valley haplotypes and a reference haplotype from New Mexico contained within the large Great Plains clade, confirming that this population is also non-indigenous.

No reference haplotypes were identical to those found in the Lompoc Valley and Tom Sawyer Lake extralimital populations. This suggests that the Lompoc and Tom Sawyer Lake populations are probably distinct introductions from those that occurred in the Salinas Valley. Given their distribution outside of the Great Basin and within the range of the California tiger salamander and their recent discovery in areas of high human population density, they 
must represent non-indigenous populations of A. tigrinum. We apparently did not sample the source region, or at least an identical representative haplotype in our reference samples and cannot conclusively show that these populations are non-indigenous based on the genetic data. However, the placement of these populations in the Great Plains clade containing many Salinas Valley haplotypes (Fig. 3) indicates that they are likely non-indigenous (if not from the same stock), and that further sampling from the native range of $A$. tigrinum might reveal the details of their source.

If we can assume the Lompoc Valley populations are non-indigenous, they represent a direct threat to the persistence of a native endangered species, the Santa Barbara distinct population segment of A. californiense. Using nuclear SNP markers we have recently identified the first known hybrid individual between these two taxa in Santa Barbara County, CA, approximately $15 \mathrm{~km}$ from the sampled Lompoc Valley populations (JR Johnson and HB Shaffer, unpublished data). The spread of non-indigenous genes through native populations of $A$. californiense in the Salinas Valley has occurred broadly and rapidly (Fitzpatrick and Shaffer 2007; Fitzpatrick et al. 2009) and raises many conservation concerns regarding the management and protection of the $A$. californiense in the face of hybridization (Ryan et al. 2009; Fitzpatrick et al. 2010). Given that contact and hybridization have just occurred in the Santa Barbara/Lompoc region, it is critical to take measures to eliminate these populations and prevent the spread of individuals/haplotypes out of the Lompoc Valley into the range of the endangered Santa Barbara distinct population segment. We view this as a critical conservation action in need of immediate attention.

Lastly, the Chocolate Canyon haplotype is contained within the Great Plains clade and grouped with reference haplotypes from Wyoming, Colorado, and Nebraska, but with no obvious association with other extralimital haplotypes. However, this population was represented by only a single individual, so shared haplotypes with the Salinas Valley may have gone undetected. Future tissue collections from Chocolate Canyon should lend more insight into the status of the population.

\section{Conclusions}

We did not find clear evidence for relictual native tiger salamander lineages in California's extralimital A. tigrinum populations, but were unable to eliminate the possibility for some sites. For the extralimital haplotypes encountered in the Clear Lake Basin, Long Valley Caldera, Salinas Valley, Lompoc Valley, Chocolate Canyon, and Tom Sawyer Lake regions, we found similar or identical haplotypes from Great Plains reference populations in the native range of A. tigrinum, indicating that these populations are the result of introductions. Our genetic data fit with anecdotal and published reports of bait dealers repeatedly importing A. tigrinum from New Mexico and Texas into California 50-60 years ago. In our opinion, conservation of native species such as the Santa Barbara subpopulation of the California tiger salamander and the Owens Valley fish assemblage should proceed under the assumption that these extralimital tiger salamander populations are non-indigenous.

Only in the Klamath Basin populations is there a realistic possibility of native, disjunct $A$. tigrinum populations. Haplotypes from Grass Lake in the southern Klamath Basin are clearly introduced and share a haplotype with the known non-indigenous Salinas Valley populations. However, the more northerly ones from Worden Vernal Pool (in Southern Oregon), MacDoel Ditch (in extreme Northern California), and Moon Reservoir (in Central Oregon) form a unique, monophyletic group of haplotypes that is most closely related to, but distinct from, those farther north in eastern Washington. Perhaps additional sampling in the Pacific Northwest will reveal that the extralimital populations in Oregon are the result of introductions from these native Washington sites, but based on our data, the possibility remains that these are relictual populations, potentially in need of protection. Our data suggest the occurrence of gene flow between the introduced Grass Lake population and at least one nearby population, and it therefore remains possible that movement of individuals from Grass Lake to the other Klamath Basin populations could result in the genetic extinction of a relict native tiger salamander in California.

Acknowledgments For collection/donation of tissue we thank M. Allaback, D. Call, E. Ervin, B. Fitzpatrick, R. Hansen, D. Keegan, B. Mori, S. Parmenter, D. Shepard, S. Stanley, J. Storrer, the Sam Noble Oklahoma Museum of Natural History, and the Texas Natural History Collection. We also thank L. Hunt, B. Johnson, G. Pauly, S. Riley, P. Spinks, and I. Wang for assistance with data collection or compilation. This work was funded by the California Department of Fish and Game (grants PO68594 and 09-002469), the National Science Foundation (grants DEB 0516475 and 0817042) and the UC Davis Agricultural Experiment Station.

Open Access This article is distributed under the terms of the Creative Commons Attribution Noncommercial License which permits any noncommercial use, distribution, and reproduction in any medium, provided the original author(s) and source are credited.

\section{Appendix}

See Table 1 
Table 1 Specimens examined

\begin{tabular}{|c|c|c|c|c|c|c|c|c|}
\hline Region & State & County & Locality & LAT & LON & Hap & $N$ & Catalogue Number \\
\hline \multirow[t]{3}{*}{$\begin{array}{l}\text { Clear Lake } \\
\text { Basin }\end{array}$} & \multirow[t]{3}{*}{ CA } & \multirow[t]{3}{*}{ Lake } & \multirow[t]{3}{*}{$\begin{array}{l}\text { Five Star Fish } \\
\text { Farm }\end{array}$} & \multirow[t]{3}{*}{39.048} & \multirow[t]{3}{*}{-122.687} & CLB01 & 13 & $\begin{array}{l}\text { HBS } 26702,26719-20,26730 \\
38114,38118,38148,38156 \\
109680-1,109683,109685 \\
109692\end{array}$ \\
\hline & & & & & & CLB02 & 1 & HBS 26715 \\
\hline & & & & & & CLB03 & 38 & $\begin{array}{l}\text { HBS } 26703-4,26707,26709, \\
26712,26718,26722-3, \\
26725-6,26729,38115-7, \\
38119-21,38145-6,38149 \\
38151-5,38157,109682 \\
109686-91,109693-4, \\
109696-8\end{array}$ \\
\hline \multirow{4}{*}{$\begin{array}{l}\text { Klamath } \\
\text { Basin }\end{array}$} & \multirow[t]{2}{*}{ CA } & \multirow[t]{2}{*}{ Siskiyou } & Grass Lake & 41.642 & -122.146 & GL01 & 17 & HBS 8974, 9082, 108881-95 \\
\hline & & & MacDoel Ditch & 41.931 & -121.939 & MD01 & 19 & $\begin{array}{l}\text { HBS } 8925,8928-30,8936, \\
8938-41,9026-35\end{array}$ \\
\hline & \multirow[t]{2}{*}{ OR } & \multirow[t]{2}{*}{ Klamath } & \multirow{2}{*}{$\begin{array}{l}\text { Worden Vernal } \\
\text { Pool }\end{array}$} & \multirow[t]{2}{*}{42.045} & \multirow[t]{2}{*}{-121.863} & WVP01 & 1 & HBS 8922 \\
\hline & & & & & & WVP02 & 6 & $\begin{array}{l}\text { HBS } 8906,8917-18,8920-1 \text {, } \\
8924\end{array}$ \\
\hline \multirow{10}{*}{$\begin{array}{l}\text { Long Valley } \\
\text { Caldera }\end{array}$} & \multirow[t]{10}{*}{ CA } & \multirow[t]{10}{*}{ Mono } & \multirow[t]{2}{*}{ ML—Hot Creek } & \multirow[t]{2}{*}{37.639} & \multirow[t]{2}{*}{-118.854} & LVC01 & 1 & HBS 21369 \\
\hline & & & & & & LVC03 & 1 & HBS 21368 \\
\hline & & & \multirow[t]{4}{*}{$\begin{array}{l}\text { ML_Laurel } \\
\text { Pond }\end{array}$} & \multirow[t]{4}{*}{37.618} & \multirow[t]{4}{*}{-118.878} & LVC01 & 28 & $\begin{array}{l}\text { HBS } 117476-9,117481-5, \\
117487,117489,117491-5, \\
117498-500,117508,117512-5 \text {, } \\
117517,117522,117525, \\
117527\end{array}$ \\
\hline & & & & & & LVC02 & 14 & $\begin{array}{l}\text { HBS } 117486,117488,117490, \\
\text { 117497, 117502-3, 117506-7, } \\
\text { 117511, 117516, 117523-4, } \\
117526,117530\end{array}$ \\
\hline & & & & & & LVC03 & 6 & $\begin{array}{l}\text { HBS } 117496,117501,117509-10 \text {, } \\
\quad 117518-19\end{array}$ \\
\hline & & & & & & LVC04 & 1 & HBS 117529 \\
\hline & & & $\begin{array}{l}\text { ML—Sherwin } \\
\text { Creek }\end{array}$ & 37.633 & -118.892 & LVC02 & 16 & $\begin{array}{l}\text { HBS } 28070-5,28077-8,28081-4 \text {, } \\
\quad 28086-9\end{array}$ \\
\hline & & & \multirow{3}{*}{$\begin{array}{l}\text { ML_-Vernal } \\
\text { Pool }\end{array}$} & \multirow[t]{3}{*}{37.652} & \multirow[t]{3}{*}{-118.925} & LVC01 & 5 & HBS 9002-3, 9005, 9007, 9020 \\
\hline & & & & & & LVC02 & 2 & HBS 9006, 9010 \\
\hline & & & & & & LVC03 & 1 & HBS 9009 \\
\hline \multirow{13}{*}{$\begin{array}{l}\text { Salinas } \\
\text { Valley }\end{array}$} & \multirow[t]{13}{*}{ CA } & \multirow[t]{13}{*}{ Monterey } & Barnwell 1 & 36.606 & -121.464 & SV13 & 1 & HBS 28805 \\
\hline & & & & & & SV16 & 2 & HBS 28806-7 \\
\hline & & & Barnwell 2 & 36.608 & -121.462 & SV12 & 1 & HBS 28975 \\
\hline & & & & & & SV16 & 1 & HBS 28976 \\
\hline & & & Barnwell 3 & 36.611 & -121.453 & SV16 & 3 & HBS 30147-8, 30150 \\
\hline & & & Christiansen & 36.720 & -121.621 & SV09 & 4 & HBS 109633-6 \\
\hline & & & Chualar Lake & 36.540 & -121.526 & SV16 & 4 & HBS 25862-5 \\
\hline & & & Chualar Tank 2 & 36.603 & -121.447 & SV14 & 1 & HBS 29296 \\
\hline & & & & & & SV16 & 2 & HBS 29293, 29294 \\
\hline & & & $\begin{array}{l}\text { Chualar Vernal } \\
\text { Pool }\end{array}$ & 36.598 & -121.453 & SV16 & 3 & HBS 25805, 25808, 25810 \\
\hline & & & Costa N3 & 36.613 & -121.451 & SV16 & 4 & HBS 28704-7 \\
\hline & & & Costa Tire & 36.618 & -121.461 & SV02 & 1 & HBS 29032 \\
\hline & & & & & & SV10 & 1 & HBS 29039 \\
\hline
\end{tabular}


Table 1 continued

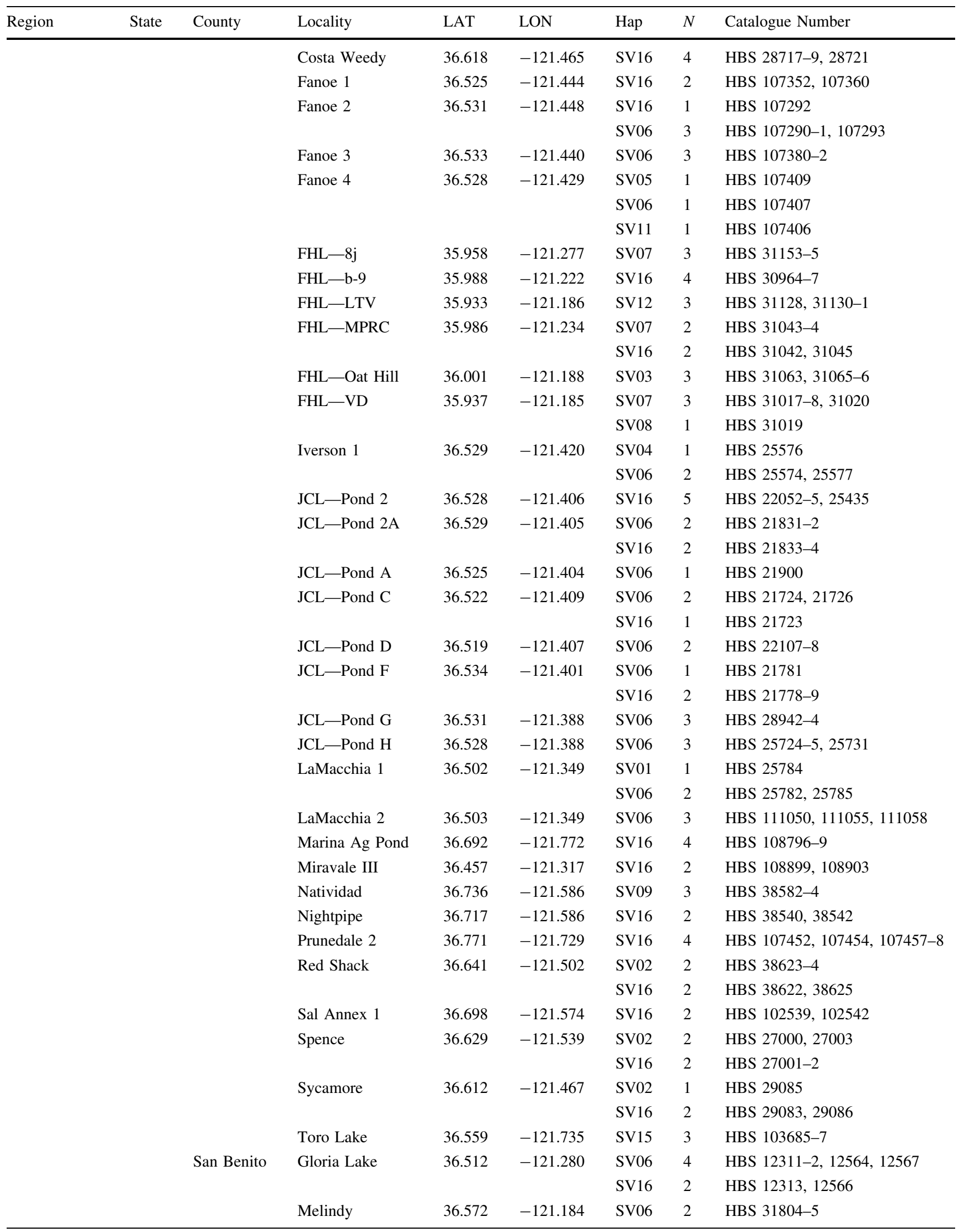


Table 1 continued

\begin{tabular}{|c|c|c|c|c|c|c|c|c|}
\hline Region & State & County & Locality & LAT & LON & Hap & $N$ & Catalogue Number \\
\hline & & Santa Clara & Bluestone & 36.946 & -121.556 & SV02 & 3 & HBS 26983, 26985-6 \\
\hline & & & Quarry & & & SV16 & 1 & HBS 26984 \\
\hline \multirow{2}{*}{$\begin{array}{l}\text { Lompoc } \\
\text { Valley }\end{array}$} & CA & Santa Barbara & Burton Mesa 2 & 34.679 & -120.487 & LV01 & 8 & HBS 28305-12 \\
\hline & & & Burton Mesa 3 & 34.678 & -120.484 & LV01 & 9 & $\begin{array}{l}\text { HBS } 28350, \\
28352,28353, \\
28355-60\end{array}$ \\
\hline \multirow[t]{7}{*}{$\begin{array}{l}\text { Other } \\
\text { populations }\end{array}$} & CA & Kern & $\begin{array}{l}\text { Tom Sawyer } \\
\text { Lake }\end{array}$ & 35.150 & -118.492 & TSL01 & 2 & HBS 108767-8 \\
\hline & & San Diego & $\begin{array}{c}\text { Chocolate } \\
\text { Canyon }\end{array}$ & 32.864 & -116.797 & CC01 & 1 & HBS 107276 \\
\hline & NV & Nye & Beatty & 36.940 & -116.707 & B01 & 2 & HBS $14564-5$ \\
\hline & & & & & & B02 & 2 & HBS 14568-9 \\
\hline & OR & Harney & Moon Reservoir & 43.415 & -119.414 & MR01 & 6 & $\begin{array}{l}\text { HBS } 9037-8,9041-2 \text {, } \\
\quad 9043,9046\end{array}$ \\
\hline & & & & & & MR02 & 1 & HBS 9045 \\
\hline & & & & & & MR03 & 1 & HBS 8911 \\
\hline \multirow{32}{*}{$\begin{array}{l}\text { Reference } \\
\text { sites }\end{array}$} & $\mathrm{AZ}$ & Coconino & Clint's Well & 34.454 & -111.396 & R04 & 1 & HBS 1466 \\
\hline & & & & & & R05 & 1 & HBS 1467 \\
\hline & & & Fracas Lake & 36.630 & -112.238 & R08 & 2 & HBS 7832-3 \\
\hline & & & Mormon Lake & 34.915 & -111.423 & R05 & 2 & HBS 1491, 1496 \\
\hline & & Yavapai & Crown King & 34.205 & -112.338 & R06 & 1 & HBS 110812 \\
\hline & $\mathrm{CO}$ & Alamosa & Blanca Wetlands & 37.549 & -105.416 & R33 & 1 & HBS 15164 \\
\hline & & & & & & $\mathrm{R} 35$ & 1 & HBS 15163 \\
\hline & & Lincoln & Limon & 39.417 & -103.676 & $\mathrm{R} 25$ & 1 & HBS 6593 \\
\hline & & Rio Grande & South Fork & 37.649 & -106.649 & R34 & 1 & HBS 15142 \\
\hline & & San Juan & Silverton & 37.747 & -107.682 & $\mathrm{R} 23$ & 1 & HBS 7124 \\
\hline & & & & & & R69 & 1 & HBS 7125 \\
\hline & & Summit & Ryan Gulch & 39.656 & -106.078 & R14 & 1 & HBS 7163 \\
\hline & & & & & & $\mathrm{R} 29$ & 1 & HBS 7169 \\
\hline & FL & Santa Rosa & Jay & 30.951 & -87.082 & R56 & 1 & HBS 6187 \\
\hline & GA & Marion & Box Springs & 32.427 & -84.654 & $\mathrm{R} 54$ & 1 & HBS 6645 \\
\hline & IA & Cass & Cumberland & 41.216 & -94.872 & R68 & 1 & HBS 10388 \\
\hline & & Grundy & New Hartford & 42.566 & -92.622 & R59 & 1 & HBS 5986 \\
\hline & & Woodbury & Lawton & 42.475 & -96.229 & $\mathrm{R} 20$ & 1 & HBS 5960 \\
\hline & ID & Bonneville & Ririe & 43.607 & -111.667 & R46 & 1 & HBS 7629 \\
\hline & & Oneida & Dammed Spring & 42.210 & -112.692 & R09 & 2 & HBS 7656-7 \\
\hline & & & Weston Canyon & 42.120 & -112.118 & R38 & 2 & HBS 7679-80 \\
\hline & IL & Cook & Kennicott Grove & 42.081 & -87.864 & R61 & 1 & HBS 4469 \\
\hline & IN & Hamilton & Carmel & 39.955 & -86.157 & R62 & 1 & HBS 8108 \\
\hline & KS & Chase & Emporia & 38.276 & -96.367 & $\mathrm{R} 51$ & 2 & HBS 5190-1 \\
\hline & & Doniphan & Troy & 39.792 & -95.073 & R68 & 1 & HBS 10245 \\
\hline & MI & Washtenaw & Goss Pond & 42.295 & -83.678 & R60 & 1 & HBS 5766 \\
\hline & MN & Cass & Motley & 46.430 & -94.654 & R63 & 1 & HBS 5587 \\
\hline & & Clearwater & Bagley & 47.651 & -95.425 & R67 & 1 & HBS 14606 \\
\hline & & Polk & Winger & 47.587 & -95.978 & R68 & 1 & HBS 14630 \\
\hline & MO & Clay & Liberty & 39.289 & -94.394 & R65 & 1 & HBS 5175 \\
\hline & & Linn & Brookfield & 39.878 & -93.075 & R64 & 1 & HBS 10011 \\
\hline & & Texas & Cabool & 37.089 & -92.060 & R66 & 1 & HBS 6074 \\
\hline
\end{tabular}


Table 1 continued

\begin{tabular}{|c|c|c|c|c|c|c|c|c|}
\hline Region & State & County & Locality & LAT & $\mathrm{LON}$ & Hap & $N$ & Catalogue Number \\
\hline & \multirow[t]{7}{*}{ MT } & Carbon & Bridger & 45.113 & -108.741 & $\mathrm{R} 46$ & 2 & HBS 7483-4 \\
\hline & & \multirow[t]{2}{*}{ Custer } & \multirow[t]{2}{*}{ Miles City } & \multirow[t]{2}{*}{46.132} & \multirow[t]{2}{*}{-105.563} & R20 & 1 & HBS 7357 \\
\hline & & & & & & $\mathrm{R} 41$ & 1 & HBS 7356 \\
\hline & & \multirow[t]{2}{*}{ Garfield } & \multirow[t]{2}{*}{ Hillside } & \multirow[t]{2}{*}{46.887} & \multirow[t]{2}{*}{-106.357} & $\mathrm{R} 43$ & 1 & HBS 7394 \\
\hline & & & & & & $\mathrm{R} 44$ & 1 & HBS 7398 \\
\hline & & \multirow[t]{2}{*}{ Musselshell } & \multirow[t]{2}{*}{ Roundup } & \multirow[t]{2}{*}{46.340} & \multirow[t]{2}{*}{-108.479} & $\mathrm{R} 42$ & 1 & HBS 7448 \\
\hline & & & & & & $\mathrm{R} 46$ & 1 & HBS 7447 \\
\hline & $\mathrm{NC}$ & Scotland & Scotland & 34.826 & -79.460 & $\mathrm{R} 53$ & 1 & HBS 5995 \\
\hline & \multirow[t]{4}{*}{ ND } & Nelson & Kloten & 47.744 & -98.078 & $\mathrm{R} 45$ & 1 & HBS 14738 \\
\hline & & Ramsey & Webster & 48.297 & -98.927 & $\mathrm{R} 46$ & 2 & HBS 5424-5 \\
\hline & & \multirow[t]{2}{*}{ Sheridan } & \multirow[t]{2}{*}{ Goodrich } & \multirow[t]{2}{*}{47.472} & \multirow[t]{2}{*}{-100.118} & $\mathrm{R} 20$ & 1 & HBS 5535 \\
\hline & & & & & & $\mathrm{R} 21$ & 1 & HBS 5536 \\
\hline & \multirow[t]{6}{*}{$\mathrm{NE}$} & \multirow[t]{2}{*}{ Antelope } & \multirow[t]{2}{*}{ Oakdale } & 42.064 & -98.010 & $\mathrm{R} 20$ & 1 & HBS 5862 \\
\hline & & & & & & $\mathrm{R} 57$ & 1 & HBS 5861 \\
\hline & & Furnas & Holbrook & 40.307 & -100.010 & $\mathrm{R} 20$ & 1 & HBS 7933 \\
\hline & & Gage & Beatrice & 40.237 & -96.797 & $\mathrm{R} 28$ & 1 & HBS 10281 \\
\hline & & Hall & Cairo & 41.000 & -98.702 & $\mathrm{R} 20$ & 2 & HBS $13506-7$ \\
\hline & & Saunders & Touhy & 41.133 & -96.854 & R39 & 1 & HBS 10442 \\
\hline & NM & Colfax & Eagle's Nest & 36.513 & -105.282 & $\mathrm{R} 18$ & 1 & HBS 15233 \\
\hline & & Grant & Corners Ranch & 32.641 & -108.572 & $\mathrm{R} 24$ & 1 & HBS 6916 \\
\hline & & & & & & $\mathrm{R} 52$ & 1 & HBS 6917 \\
\hline & & & Silver City & 32.784 & -108.231 & R48 & 2 & HBS 6950-1 \\
\hline & & & Tyrone & 32.809 & -108.736 & $\mathrm{R} 24$ & 2 & HBS 6934-5 \\
\hline & & Lincoln & Capitan & 33.541 & -105.601 & R47 & 1 & HBS 7011 \\
\hline & & & & & & R48 & 1 & HBS 7012 \\
\hline & & McKinley & Thoreau & 35.885 & -108.239 & R03 & 1 & HBS 7102 \\
\hline & & Rio Arriba & Brazos & 36.754 & -106.554 & R01 & 1 & HBS 24702 \\
\hline & & & Tres Piedras & 36.649 & -105.983 & R36 & 1 & HBS 18442 \\
\hline & & Socorro & San Antonio & 33.883 & -106.682 & R02 & 2 & HBS 6957-8 \\
\hline & & & White Sands & 33.825 & -106.261 & $\mathrm{R} 48$ & 1 & HBS 7004 \\
\hline & & & & & & R50 & 1 & HBS 7003 \\
\hline & & Torrance & Encino & 34.876 & -105.482 & $\mathrm{R} 49$ & 1 & HBS 7060 \\
\hline & $\mathrm{OK}$ & Beckham & Sandy Sanders & 35.068 & -99.836 & $\mathrm{R} 17$ & 2 & OMNH 40368-9 \\
\hline & & Ellis & Packsaddle & 35.897 & -99.698 & $\mathrm{R} 30$ & 1 & OMNH 41728 \\
\hline & & & & & & R51 & 3 & $\begin{array}{l}\text { OMNH 41727, } \\
41729-30\end{array}$ \\
\hline & $\mathrm{SC}$ & Aiken & Ellenton Bay & 33.221 & -81.747 & R55 & 1 & HBS 6652 \\
\hline & SD & Beadle & Virgil & 44.295 & -98.486 & R19 & 1 & HBS 14789 \\
\hline & & & & & & $\mathrm{R} 46$ & 1 & HBS 14788 \\
\hline & & Butte & Belle Fourche & 44.680 & -103.815 & R46 & 2 & HBS 7300, 7304 \\
\hline & & Deuel & Altamont & 44.846 & -96.688 & R46 & 2 & HBS 14818-9 \\
\hline & $\mathrm{TN}$ & Montgomery & Palmyra & 36.429 & -87.471 & R58 & 1 & HBS 5615 \\
\hline & $\mathrm{TX}$ & Collingsworth & Marilla & 35.013 & -100.379 & R16 & 1 & TNHC 72507 \\
\hline & & & & & & $\mathrm{R} 47$ & 1 & TNHC 72506 \\
\hline & & Jeff Davis & Fort Davis & 30.565 & -103.940 & R48 & 2 & HBS 7926-7 \\
\hline & UT & Cache & Porcupine Reservoir & 41.518 & -111.736 & $\mathrm{R} 46$ & 2 & HBS 16004-5 \\
\hline & & Garfield & Boulder & 37.922 & -111.424 & R07 & 2 & HBS 7827-8 \\
\hline & & Kane & Kanab Creek & 37.102 & -112.548 & R07 & 2 & HBS 7868-9 \\
\hline
\end{tabular}


Table 1 continued

\begin{tabular}{|c|c|c|c|c|c|c|c|c|}
\hline Region & State & County & Locality & LAT & LON & Hap & $N$ & Catalogue Number \\
\hline & & Salt Lake & Salamander Lake & 40.701 & -111.607 & R10 & 2 & HBS 7712-3 \\
\hline & & Uintah & Vernal & 40.455 & -109.538 & $\mathrm{R} 46$ & 1 & HBS 20205 \\
\hline & & Utah & Thistle & 39.994 & -111.493 & R15 & 1 & HBS 7763 \\
\hline & & Wasatch & Fruitland & 40.193 & -110.933 & $\mathrm{R} 13$ & 1 & HBS 20183 \\
\hline & & & & & & $\mathrm{R} 33$ & 1 & HBS 20181 \\
\hline & & Washington & Lucky D Ranch & 37.216 & -112.974 & R09 & 2 & HBS 7877-8 \\
\hline & & Wayne & Hanksville & 38.374 & -110.714 & R37 & 1 & HBS 18162 \\
\hline & & & & & & $\mathrm{R} 40$ & 1 & HBS 18161 \\
\hline & \multirow[t]{4}{*}{ WA } & Adams & 4th of July Lake & 47.243 & -117.986 & R11 & 1 & HBS 6883 \\
\hline & & & Wildcat Lake & 46.727 & -118.157 & R12 & 1 & HBS 6822 \\
\hline & & Grant & $\begin{array}{l}\text { Potholes } \\
\text { Reservoir }\end{array}$ & 46.960 & -119.263 & R11 & 1 & HBS 6792 \\
\hline & & Whitman & Lake Chinook & 46.726 & -117.153 & R12 & 2 & HBS-2 \\
\hline & WI & Dane & Oregon & 42.951 & -89.378 & R68 & 1 & HBS 5154 \\
\hline & WY & Fremont & Diversion Dam & 48.217 & -98.961 & $\mathrm{R} 32$ & 1 & HBS 7569 \\
\hline & & & Togwatee Pass & 43.585 & -109.783 & $\mathrm{R} 46$ & 2 & HBS 7584-5 \\
\hline & & Goshen & Hawk Springs & 41.723 & -104.264 & $\mathrm{R} 22$ & 1 & HBS 7242 \\
\hline & & & & & & R27 & 1 & HBS 7241 \\
\hline & & Hot Springs & Black Mountain & 43.740 & -108.048 & R46 & 2 & HBS 7525,7530 \\
\hline & & Laramie & Midway & 41.365 & -104.463 & R26 & 1 & HBS 7200 \\
\hline & & & & & & R31 & 1 & HBS 7199 \\
\hline & & Niobrara & Boner Road & 43.083 & -104.364 & R46 & 2 & HBS 7277, 7281 \\
\hline & & Teton & Wilson & 43.488 & -110.828 & R42 & 1 & HBS 7602 \\
\hline & & & & & & R46 & 1 & HBS 7603 \\
\hline
\end{tabular}

\section{References}

Allendorf FW, Leary RF, Spruell P, Wenburg JK (2001) The problems with hybrids: setting conservation guidelines. Trends Ecol Evol 16:613-622

Arntzen JW, Thorpe RS (1999) Italian crested newts (Triturus carnifex) in the basin of Geneva: distribution and genetic interactions with autochthonous species. Herpetologica 55:423-433

Beebee TJC, Griffiths RA (2005) The amphibian decline crisis: a watershed for conservation biology? Biol Conserv 125:271-285

Blaustein AR, Wake DB (1990) Declining amphibian populations: a global phenomenon. Trends Ecol Evol 5:203-204

Bowers W, Smith R, Messmer R, Edwards C, Perkins R (1999) Conservation status of Oregon Basin redband trout. Oregon Department of Fish and Wildlife

Bradford DF (1989) Allotopic distribution of native frogs and introduced fishes in high Sierra Nevada lakes of California: implication of the negative effect of fish introductions. Copeia 1989:775-778

Bryant D, Moulton V (2004) NeighborNet: an agglomerative method for the construction of planar phylogenetic networks. Mol Biol Evol 21:255-265

Bury RB, Luckenbach RA (1976) Introduced amphibians and reptiles in California. Biol Conserv 10:1-14

Chen Y, Parmenter S, May B (2007) Introgression between Lahontan and endangered Owens Tui Chubs, and apparent discovery of a new Tui Chub in the Owens Valley, California. Conserv Genet $8: 221-238$
Collins JP (1981) Distribution, habitats and life history variation in the tiger salamander, Ambystoma tigrinum, in east-central and southeast Arizona. Copeia 1981:666-675

Collins JP, Jones TR, Berna HJ (1988) Conservation and management of genetically distinctive populations: The case of the Huachuca tiger salamander (Ambystoma tigrinum stebbinsi Lowe). In: Szaro RC, Severson KE, Patton DR (eds) Proceedings of the Symposium: Management of Amphibians, Reptiles, and Small Mammals in North America. USDA Forest Service GTR-RM166, Rocky Mountain Forest and Range Experiment Station, Fort Collins, CO, pp 45-53

Edgar RC (2004) MUSCLE: a multiple sequence alignment method with reduced time and space complexity. BMC Bioinformatics $5: 113$

Elton CS (1958) The ecology of invasions by plants and animals. Methuen, London, UK

Ervin EL, Burkhardt TR (2006) Ambystoma tigrinum mavortium (Barred Tiger Salamander). Extralimital Populations. Herpetol Rev 37:435

Fisher RN, Shaffer HB (1996) The decline of amphibians in California's Great Central Valley. Conserv Biol 10:1387-1397

Fitzpatrick BM, Shaffer HB (2007) Introduction history and habitat variation explain the landscape genetics of hybrid tiger salamanders. Ecol Appl 17:598-608

Fitzpatrick BM, Johnson JR, Kump DK, Shaffer HB, Smith JJ et al (2009) Rapid fixation of non-native alleles revealed by genomewide SNP analysis of hybrid tiger salamanders. BMC Evol Biol 9:176 
Fitzpatrick BM, Johnson JR, Kump DK, Smith JJ, Voss SR et al (2010) Rapid spread of invasive genes into a threatened native species. Proc Natl Acad Sci 107:3606-3610

Gamradt SC, Kats LB (1996) Effect of introduced crayfish and mosquitofish on California newts. Conserv Biol 10:1155-1162

Hayes MP, Jennings MR (1986) Decline of ranid frog species in western North America: are bullfrogs (Rana catesbeiana) responsible? J Herpetol 20:490-509

Holsbeek G, Mergeay J, Hotz H, Plötner J, Volckaert FAM et al (2008) A cryptic invasion within an invasion and widespread introgression in the European water frog complex: consequences of uncontrolled commercial trade and weak international legislation. Mol Ecol 17:5023-5035

Huson DH (1998) SplitsTree: analyzing and visualizing evolutionary data. Bioinformatics 14:68-73

Huson DH, Bryant D (2006) Application of phylogenetic networks in evolutionary studies. Mol Biol Evol 23:254-267

Jennings MR, Hayes MP (1994) Amphibian and reptile species of special concern in California. California Department of Fish and Game, Inland Fisheries Division

Kiesecker JM, Blaustein AR (1998) Effects of introduced bullfrogs and smallmouth bass on microhabitat use, growth, and survival of native red-legged frogs (Rana aurora). Conserv Biol 12:776-787

Knapp RA, Matthews KR (2000) Non-native fish introductions and the decline of the mountain yellow-legged frog from within protected areas. Conserv Biol 14:428-438

Kolar CS, Lodge DM (2001) Progress in invasion biology: predicting invaders. Trends Ecol Evol 16:199-204

Kraus F (2009) Alien reptiles and amphibians: a scientific compendium and analysis. Springer, Dordrecht

Kupferberg SJ (1997) Bullfrog (Rana catesbeiana) invasion of a California river: the role of larval competition. Ecology 78:1736-1751

Lawler SP, Dritz D, Strange T, Holyoak M (1999) Effects of introduced mosquitofish and bullfrogs on the threatened California red-legged frog. Conserv Biol 13:613-622

Lodge DM (1993) Biological invasions: lessons for ecology. Trends Ecol Evol 8:133-137

Moyle PB (1973) Effects of introduced bullfrogs, Rana catesbeiana, on the native frogs of the San Joaquin Valley, California. Copeia 1973:18-22

Mullen DA, Stebbins RC (1978) An addition to the amphibian fauna of California. Great Basin Nat 38:429-437

Nussbaum RA, Brodie ED Jr, Storm RM (1983) Amphibians and reptiles of the Pacific Northwest. University Press of Idaho, Moscow, ID

Pearl CA, Adams MJ, Bury RB, McCreary B (2004) Asymmetrical effects of introduced bullfrogs (Rana catesbeiana) on native ranid frogs in Oregon. Copeia 2004:11-20
Petranka JW (1998) Salamanders of the United States and Canada. Smithsonian Institution Press, Washington, DC

Picco A, Collins J (2008) Amphibian commerce as a likely source of pathogen pollution. Conserv Biol 22:1582-1589

Rhymer JM, Simberloff D (1996) Extinction by hybridization and introgression. Annu Rev Ecol Syst 27:83-109

Riley SPD, Shaffer HB, Voss SR, Fitzpatrick BM (2003) Hybridization between a rare, native tiger salamander (Ambystoma californiense) and its introduced congener. Ecol Appl 13: $1263-1275$

Rozen S, Skaletsky H (2000) Primer3 on the WWW for general users and for biologist programmers. In: Krawetz S, Misener S (eds) Bioinformatics methods and protocols: methods in molecular biology. Humana Press, Totowa, NJ, pp 365-386

Ryan ME, Johnson JR, Fitzpatrick BM (2009) Invasive hybrid tiger salamander genotypes impact native amphibians. Proc Natl Acad Sci U S A 106:11166-11171

Sambrook J, Russell DW (2001) Molecular cloning: a laboratory manual, 3rd edn. Cold Spring Harbor Laboratory Press, Cold Spring Harbor, N.Y

Samuels AK, Weisrock DW, Smith JJ, France KJ, Walker JA et al (2005) Transcriptional and phylogenetic analysis of five complete ambystomatid salamander mitochondrial genomes. Gene 349:43-53

Shaffer HB, McKnight ML (1996) The polytypic species revisited: genetic differentiation and molecular phylogenetics of the tiger salamander Ambystoma tigrinum (Amphibia: Caudata) complex. Evolution 50:417-433

Shaffer HB, Trenham PC (2005) Ambystoma californiense (Gray, 1853) California tiger salamander. In: Lannoo MJ (ed) Amphibian declines. The conservation status of United States species. University of California Press, Berkeley, California, pp 605-608

Slater JR (1934) Ambystoma tigrinum in the State of Washington. Copeia 1934:189-190

Stamatakis A, Hoover P, Rougemont J (2008) A rapid bootstrap algorithm for the RAxML web servers. Syst Biol 57:758-771

Stebbins RC (2003) Western amphibians and reptiles. Haughton Mifflin Company, New York

Storfer A, Mech SG, Reudink MW, Ziemba RE, Warren J et al (2004) Evidence for introgression in the endangered Sonora tiger salamander, Ambystoma tigrinum stebbinsi (Lowe). Copeia 2004:783-796

Weisrock DW, Shaffer HB, Storz BL, Storz SR, Voss SR (2006) Multiple nuclear gene sequences identify phylogenetic species boundaries in the rapidly radiating clade of Mexican ambystomatid salamanders. Mol Ecol 15:2489-2503 